\title{
RATING IN THE ASSESSMENT OF INVESTMENT PROPERTY
}

\author{
Katarzyna Śmietana, Ph.D \\ University of Economics in Katowice \\ e-mail: katarzyna.smietana@ue.katowice.pl \\ Jan Konowalczuk, Ph.D \\ University of Economics in Katowice \\ e-mail: jan.konowalczuk@ue.katowice.pl
}

\section{Anna Maszczyk, M.Sc}

University of Economics in Katowice

e-mail: anna.maszczyk@ue.katowice.pl

\begin{abstract}
The implementation of rating procedures is associated with searching for tools that provide an objective and standardized assessment of investment risk. For this reason, rating is an important and often essential element of investment decision-making processes which determines the development of the capital market, including the real estate investment market. In the investment property market, not only does rating provide transparency of property risk, but it can also be used for real estate portfolio analysis, investment controlling, and the analysis of factors determining investment decisions (ESV 2012).

In this article, the authors present an assessment of the suitability of the rating recommended by TEGoVA for properties considered as active investments, namely properties in the course of development and intended for future development projects. The analysis will include criteria affecting the assessment of property quality and risk, taking into account four classes: market, location, property characteristics, and the quality of cash flows. The study will allow to identify assessment parameters and determine a recommended scope for the analysis of real estate investment potential.
\end{abstract}

Key words: property rating, property and market rating, investment property.

JEL Classification: G11, R30.

Citation: Śmietana K., Konowalczuk J., Maszczyk A., 2014, Rating in the assessment of investment property, Real Estate Management and Valuation, vol. 22, no. 2, s. 98-107.

DOI: 10.2478/remav-2014-0021

\section{Introduction}

In unstable conditions and a highly complex business environment, making decisions under uncertainty is an inherent element of process implementation. In modern enterprises, a bid to limit the broadly understood sense of risk exposes the need for the standardization of procedures and adaptation of methods and techniques that enable making rational decisions.

The multiplicity of factors affecting the quality of real estate as investment assets and the volatility of market conditions accompanying the decision-making processes determine the use of comprehensive tools for assessing the safety of investments, the objectified results of which should be presented in a standardized form.

As a system resulting from the assessment of economic phenomena (WÓJCICKA 2010), rating is viewed in the context of a company's assessment, its creditworthiness, and the security of issued 
financial instruments, as a strategic indicator specifying the degree of confidence in a given entity (KOWALCZYK 2006), and a system that could assess the quality of non-financial assets of the company, i.e. real estate (TEGoVA 2004, ESV 2012). Given the observed trends in the standardization of management procedures including risk management, credit rating has become an indispensable element of modern financial management. It is used today as an instrument for determining the level of investment risk and managing company value (DZIAWGO 2010).

Rating is regarded as an objectified tool for assessing the quality of property, the state of the property market and prospects for its development, and can be used by the market participants, including "individual professional and non-professional investors, institutional investors, developers and other investors in their choice of investment location and in determining the profitability of investment processes in the real estate market," (RENIGIER-BIŁOZOR, WIŚNIEWSKI 2012, p. 68).

Assuming that investment properties constitute separate "profit centers" (NALEPKA 2006) and are regarded as active investments which require active management (KUCHARSKA-STASIAK 2006), their market value, as well as company market value "are managed in order to achieve a possibly steady, long-term increase over time," (DZIAWGO 2010; KONOWALCZUK, RAMIAN 2012). If property is to follow the two strategies: maximize income and market value (KUCHARSKA-STASIAK 2006, 2013) and maximize income as well as optimize property market value, the application of a strategy that takes into account not only economic, but also social and environmental aspects appears to be justifiable due to the need of acknowledging the concept of corporate social responsibility and socially responsible investment in the property market (MARCINEK 2012).

Decisions made in the process of property value management require the use of risk assessment instruments in order to reduce the uncertainty accompanying investment activities. The property and market rating developed by TEGoVA seems to be a useful method of risk assessment.

The purpose of this paper is to evaluate the usefulness of formalized rating procedures recommended by TEGoVA in relation to properties seen as investment assets. It is assumed that the rating procedures may be a useful tool for providing an objective and standardized assessment of investment risk. For this reason, rating may be an important element of the decision-making process with regard to investment assets.

\section{Property as active investment}

Property that is an investment asset is maintained by the owner in order to obtain direct proceeds from rent and capital appreciation, and for the realization of benefits as a result of the implemented development processes. European Valuation Standards distinguish between three types of investment property (ESW 2012):

- property held as an investment to generate income and/or increase in value,

- property in the course of development,

- property held for future development projects.

Real estate held as an investment is property with completed construction work, owned for the purpose of leasing in order to generate rental income, and whose tenants are third parties not connected with the investor. Property in the course of development is purchased with the intention of acquiring tenants unrelated to the investor and requires renovations or repair work which vary in scope. This category includes any property where work is already in progress and property where work will start in the future, provided that all required permits and consents have been obtained, and the execution of investment agreements is in force.

Real estate held for future development projects includes property acquired with the intention of redevelopment in the future due to its investment potential. According to typology proposed by NCREIF ${ }^{1}$, investment real estate comprises strategic and stable property, rental investment property (core) with prospects for development (value added), and speculative "opportunistic" property (ŚMIETANA 2013, p. 55).

Strategic property is characterized as strategic assets providing stable cash flows. The second type is represented by assets with a high potential to increase in value, while speculative property described as an alternative investment is associated with land development projects (BACZEWSKI, HANDS, LATHEM 2003).

1 The National Council of Real Estate Investment Fiduciaries. 
Rating analysis that covers four classes of criteria (market, location, characteristics and quality of cash flows) should include the following key determinants of the quality of investment properties, including development ones:

- market - effective demand for a specific type of property,

- location - suitable location that stimulates long-term growth of property market value,

- property - high-quality urban and architectural concept where the structure of the facility corresponds to the market demand and, at the same time, guarantees adequate spatial efficiency, high quality of construction works, professional management and maintenance of high standards of real estate, environmental sustainability, a funding model, the cost of capital, and real estate marketing

- quality of cash flow - financial management to ensure the stabilization of cash flows. Property is rated in relation to average market values for the selected parameters reflecting typical evaluation and results obtained on the market, while the elements of the evaluation are standard factors, including market, functional and environmental standards.

\section{Assessment criteria for the quality of investment property}

\subsection{Rating in the assessment of property quality according to TEGoVA standards}

The primary purpose of rating tools was to assess the risk of issuers of securities in capital markets. Over time, the increasing sensitivity to risk stimulated by the Basel Committee on Banking Supervision and the European institutions have enhanced the importance of rating systems for both capital market investors and banking supervision (EVS 2012, pp. 211-2012).

In response to the lack of rating systems that meet the stringent requirements of individual valuations of resources, in 2004 TEGoVA (The European Group of Valuers Associations) developed Property and Market Rating (PAM) for the assessment of real estate quality. PAM is a versatile tool for estimating the quality of real estate. Individual modules can be used to evaluate specific property or to valuate for the purpose of securitization, portfolio analysis, and controlling. The tool allows objective and standardized risk assessment to be performed by identifying threats and opportunities, and revealing the quality of the project in a given market. By indicating the "risk and opportunities" of real estate, PAM helps to increase the level of transparency of property valuation and assessment (TEGoVA 2003, pp. 4-6).

Factors taken into account while making an investment include the quality of a hypothetically completed property, risk, and investment opportunities. This quality is assessed by medium-term sale prospects at a price agreed upon between parties with access to property and market information. Sale prospects are determined on the rating date due to the continually changing circumstances of the investment which result from the status of building permits, the implementation of the investment project, the level of commercialization, etc. (EVS 2012, pp. 211-2012).

The property and market rating developed by TEGoVA is based on the formula used by credit rating agencies and internal rating scales of banks. It consists of 10 grades, where 1 stands for an excellent rating and 10 for a disastrous one. A rating below 5 presents opportunities, a rating above 5 expresses risks. Features affecting the quality of a property are divided into four criteria classes: market, location, property, and the quality of the property cash flow. Each class consists of several sub-criteria weighted due to their impact on the medium-term sales prospects of property in a relevant market. Objective sub-criteria include purchase power and the efficiency of the used space. Subjective sub-criteria comprise the quality of the architecture, completion of construction, and the appearance or location of the plot of land (TEGoVA 2003, pp. 8-9). The method of weighting a given sub-criterion varies depending on different property types, which reflects the diverse circumstances of property quality assessment, depending on its intended use. The PAM rating system distinguishes between four types of property (EVS 2012, pp. 212): residential, commercial, office, distribution (logistics) and production.

For a property investment to be rated, all of the above criteria classes must be assessed as if the said investment had been completed before the rating day. The assessment must be focused on the sales prospects of a hypothetically completed investment since this is the conclusion of the undertaking for the investors. For such a specific rating, a fifth class of criteria must be added - risks and opportunities of investment property and its project. The project is understood as the planning, construction and commercialization of buildings on the property within the existing construction 
regulations. The assessment of the project sales prospects on the rating date is carried out by means of a matrix that takes into account all the combinations of the ratings of hypothetical completed investments with regard to risk ratings and opportunities for investment (TEGoVA 2003, pp. 8-9).

An appraiser's guidebook on the European market and property ratings provides general guidance on measurement standards. Measurable sub-criteria can be evaluated on the basis of the standard comparison. However, what is crucial for the credibility of the PAM rating system is a common understanding of the subjective sub-criteria rating by market participants. To achieve such uniformity of subjective sub-criteria assessment, measurement standards must be defined for each of the subcriteria, with the assumption that different types of property are distinguished. These norms must establish a standard that will represent an average for each criterion in a given market, which allows for a relative assessment of property with respect to the parameter constituting a point of reference and a standard for comparison in the benchmarking process. In the analysis of property quality, it should be emphasized how important the assessment of environmental sustainability is, because "green" standards and tools for granting "green" ratings in the comprehensive assessment of buildings are very important at the stage of creating the concept, planning, and use. Sustainability has not been identified as an independent criterion, but a significant part of assessment parameters coincide with the sub-criteria and factors influencing the quality of property.

\subsection{Standard as a criterion for assessing the quality of investment property}

What is taken into account in the process of creating real estate value are specific economic characteristics of the property, factors included in financial, technical, legal, and marketing areas, as well as relationships with property users and the standard elements that determine the classes of objects characterized by different attributes. The synergy of matching elements such as location, usability, and market and operating standard determine property value and its investment attractiveness. The quality of location and the elements of the usability standard, including the environmental one, undergo comprehensive assessment as they affect the real estate market standard. The standard comprises the quality of the building, including the leased space, characterized by technical, functional, behavioral, organizational, and economic features (STACHURA 2007, pp. 49-50; FORYŚ 2006, p. 37). Despite the lack of regulations of applicable standards, property market participants adopt the contractual criteria that become guidelines for the design of functional solutions and use of technologies, including the pro-ecological ones (investment standard). The guidelines are a group of qualitative characteristics which, in practice, reflect the expectations (preferences) of users of the space and the visions of architects presented in technical solutions applied in modern construction, architecture trends, and fashion. A standard is understood as a certain common measurement, a fixed criterion which specifies certain characteristics of the examined object. It is a set of specific properties (a set of parameters) that should characterize a given object and provide adequate levels of quality, safety, and compliance with the applicable standards. The adopted property standard assessment criteria are presented in Table 1, while a list of parameters - assessment indicators (more: ŚMIETANA, RAMIAN 2014) - is illustrated collectively in Table 2.

Table 1

Criteria for assessing the quality of investment property

\begin{tabular}{|c|c|c|c|}
\hline Property type & $\begin{array}{c}\text { Property held as an } \\
\text { investment to generate } \\
\text { income and/or increase in } \\
\text { value }\end{array}$ & $\begin{array}{c}\text { Property in the course of } \\
\text { development }\end{array}$ & $\begin{array}{c}\text { Property held for future } \\
\text { development }\end{array}$ \\
\hline Market standard & $\begin{array}{l}\text { Profitability of property } \\
\text { determined with } \\
\text { changes in the value of } \\
\text { capital taken into } \\
\text { account } \\
\text { Economic and financial } \\
\text { comparative assessment }\end{array}$ & $\begin{array}{l}\text { Assessment of changes in the } \\
\text { economic location of property }\end{array}$ & $\begin{array}{c}\text { Assessment of location potential } \\
\text { required to stimulate a long- } \\
\text { lasting increase in property } \\
\text { market value }\end{array}$ \\
\hline Usability standard & $\begin{array}{c}\text { Quality of usability - } \\
\text { determinants of operating }\end{array}$ & Quality of construction work & $\begin{array}{l}\text { Quality of urban planning and } \\
\text { architectural concept }\end{array}$ \\
\hline
\end{tabular}


standards

Qualitative and quantitative

economic-financial and

technical-economic

comparative assessment

\begin{tabular}{cccc}
\hline $\begin{array}{c}\text { Environmental } \\
\text { standard }\end{array}$ & $\begin{array}{c}\text { Environmental sustainability } \\
\text { in operation } \\
\text { Quantitative and qualitative } \\
\text { ratio analysis }\end{array}$ & $\begin{array}{c}\text { Environmental sustainability } \\
\text { in the investment process }\end{array}$ & $\begin{array}{c}\text { Environmental sustainability in } \\
\text { the process of planning and } \\
\text { designing - environmental } \\
\text { impact assessment }\end{array}$ \\
\hline $\begin{array}{c}\text { Recommended type } \\
\text { of economic analyses }\end{array}$ & $\begin{array}{c}\text { Due diligence analysis } \\
\text { Highest \& best use analysis }\end{array}$ & Highest \& best use analysis \\
\hline
\end{tabular}

Source: Own study.

A recommended type of economic analysis was proposed for the distinguished types of investment property. It includes a widely understood property audit (due diligence analysis) for rental investment property and an analysis of best use (KUCHARSKA-STASIAK 2012, pp. 21-33) for real estate with a potential increase in value.

\subsection{Eco-rating of investment property}

The issue of environmental sustainability, which is the idea of sustainable building development, has become essential in the quality assessment of property. Sustainable buildings are designed to provide a sustainable balance of environmental, social and economic aspects in all phases of their life cycles (LÜTZKENDORF, LORENZ 2005, 2007). Sustainability is understood as a responsibly created and managed construction environment which takes into account the principles of environmental protection and the efficient use of resources (BELNIAK, GŁUSZAK, ZIĘBA 2013, pp. 69-70).

"Green" or "sustainable" buildings consume resources in the form of energy, water, and materials, and use land in a more efficient manner than buildings constructed according to the lowest applicable standards. They also produce less waste, emit fewer harmful substances and offer a better working environment - their design considers social, ecological and environmental aspects (EVS 2013, pp. 177178). Sustainable buildings are facilities whose attributes minimize their environmental impact throughout their life cycles. Their management is focused on optimizing functionality for owners, tenants and the public, while minimizing the consumption of natural resources and the environmental impact.

With the growing importance of corporate social responsibility (CSR) and socially responsible investing (SRI), environmental aspects, namely "green" standards, are becoming increasingly important for the real estate market. Including not only economic, but also social and environmental effects in property management corresponds to the idea of responsible property investment (RPI) (MARCINEK 2012, pp. 163-185).

The idea of responsible property investment (RPI) should be taken into account when investing, as it entails maximizing positive effects while minimizing the negative ones of the ownership, management and development of property, for the benefit of society and the natural environment (EVS 2012, p.175). The following basic elements are considered in their analysis (BELNIAK, GEUSZAK, ZIĘBA 2013, p. 72; ESW 2012, pp. 178-179):

- location - a good use of the existing transport infrastructure with a specific transport policy for tenants,

- environmental impact - concern about the ecology of a place, careful planning, design, landscaping, surroundings,

- efficient use of resources - non-renewable energy, water efficiency, waste management,

- use of environmentally friendly materials in construction,

- avoidance of toxic and other harmful emissions,

- quality of the work environment - healthy and comfortable environment for building occupiers (maximum use of daylight, high indoor air quality),

- building design and layout that allows re-adaptation, 
- building management systems utilized in accordance with the principle of minimizing the consumption of non-renewable resources.

The "green" standards and tools for granting "green" ratings in the comprehensive assessment of buildings, which takes into account ecological, financial and socially sustainable development criteria, are in line with international sustainable building certification schemes. They offer standardized systems for the assessment and certification of energy-saving green buildings. The acknowledged voluntary, internationally-recognized systems include: BREEAM ${ }^{2}$ (Building Research Establishment Environmental Assessment Method) and LEED ${ }^{3}$ (Leadership in Energy and Environmental Design).

\section{Quality assessment parameters for investment property}

The analysis of investment property assessment criteria has led to the development of a synthetic listing of three criteria classes: location, property and quality of cash flows. The market has been omitted in the listing as a criterion whose assessment parameters, their sub-criteria and proposed evaluation indicators, have all been acknowledged in the relevant literature. The selection of the criteria classes was justified by the subjective usefulness of particular characteristics in assessing the quality of real estate as an active investment. Weights assigned accordingly to individual indicators, sub-criteria and class criteria in property assessment depend largely on property type, and reflect the impact of various parameters on quality and investment potential.

Table 2

Assessment criteria for location, property, and quality of cash flows with acknowledgement of environmental sustainability

Location Property Quality of cash flows

1.1. Suitability for property type 2.1. Architecture/type of and target occupiers construction

\begin{tabular}{|c|c|c|c|c|c|}
\hline 1.2 . & $\begin{array}{l}\text { Image of the quarter (office } \\
\text { district) and the location }\end{array}$ & 2.1.1. & Project quality & 3.1.1. & $\begin{array}{l}\text { Number of tenants, their profile } \\
\text { and solvency, careful selection of } \\
\text { tenants }\end{array}$ \\
\hline 1.2.1. & Centrality & 2.1.2. & Insulation, shading & 3.1.2. & $\begin{array}{l}\text { Structure of lease, duration of } \\
\text { lease agreements }\end{array}$ \\
\hline 1.2.2. & $\begin{array}{l}\text { Rating of the area, location of } \\
\text { other industry entities }\end{array}$ & 2.1.3. & Functional property layout & 3.2 . & $\begin{array}{l}\text { Rental growth } \\
\text { potential/value growth } \\
\text { potential }\end{array}$ \\
\hline 1.2.3. & Image, reputation of location & 2.2 . & Fit-out & 3.2.1. & Lease growth potential \\
\hline 1.3 . & $\begin{array}{l}\text { Quality of transportation } \\
\text { infrastructure of the plot } \\
\text { and quarter }\end{array}$ & 2.2.1 & $\begin{array}{l}\text { Quality of technical } \\
\text { equipment and building } \\
\text { security }\end{array}$ & 3.2.2. & $\begin{array}{l}\text { Value growth potential } \\
\text { (estimated resale price change) }\end{array}$ \\
\hline 1.3.1. & Airports & 2.2.2. & $\begin{array}{l}\text { Telecommunication and } \\
\text { information systems }\end{array}$ & 3.3 & Letting prospects \\
\hline 1.3.2. & Railway & 2.2.3. & $\begin{array}{l}\text { Internal installations and } \\
\text { fitting* }\end{array}$ & 3.4. & Vacancy/letting situation \\
\hline 1.3.3. & Public transport & 2.2.4. & Social facilities & 3.5. & $\begin{array}{l}\text { Recoverable and non- } \\
\text { recoverable operating } \\
\text { expenses }\end{array}$ \\
\hline 1.3.4. & Road access & 2.3. & Structural condition & 3.5 .1 & Level of operating costs \\
\hline 1.3.5. & Parking spaces, parking options & 2.3.1. & $\begin{array}{l}\text { Age, year of construction, } \\
\text { type of construction }\end{array}$ & 3.5 .2 & $\begin{array}{l}\text { Opportunities to transfer } \\
\text { administrative and management } \\
\text { costs to tenants }\end{array}$ \\
\hline
\end{tabular}

3.1. Tenant/occupier situation Number of tenants, their profile and solvency, careful selection of Structure of lease, duration of lease agreements

potential/value growth potential

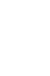




\begin{tabular}{|c|c|c|c|c|c|}
\hline 1.4. & $\begin{array}{l}\text { Quality of local supply } \\
\text { infrastructure of the plot } \\
\text { and quarter for target } \\
\text { occupiers }\end{array}$ & 2.3.2. & $\begin{array}{l}\text { Degree of modernization, } \\
\text { revitalization of the property }\end{array}$ & 3.6. & $\begin{array}{l}\text { Usability by third parties } \\
\text { and/or alternative usability } \\
\text { options }\end{array}$ \\
\hline 1.4.1. & $\begin{array}{l}\text { Shopping centers, service } \\
\text { points, public and medical } \\
\text { infrastructure, administrative } \\
\text { authorities }\end{array}$ & 2.3.3. & $\begin{array}{l}\text { State of maintenance, } \\
\text { building maintenance backlog }\end{array}$ & & \\
\hline 1.4 .2 & Restaurants and catering & 2.4. & Plot situation & & \\
\hline 1.5. & Acts of God & 2.4 .1 & Topography, plot layout & & \\
\hline 1.5 .1 & Natural disasters & 2.4 .2 & $\begin{array}{l}\text { Geotechnical, geological, } \\
\text { archaeological conditions }\end{array}$ & & \\
\hline 1.5.2. & $\begin{array}{l}\text { Environmental pollution, } \\
\text { contamination of brownfields }\end{array}$ & 2.4.3. & Contaminations & & \\
\hline 1.5.3. & $\begin{array}{l}\text { Technical disasters, man-made } \\
\text { disasters }\end{array}$ & 2.4.4. & $\begin{array}{l}\text { Infrastructure, internal and } \\
\text { external availability }\end{array}$ & & \\
\hline 1.5 .4 & Location safety & 2.4 .5 & $\begin{array}{l}\text { Exterior amenities, associated } \\
\text { structures }\end{array}$ & & \\
\hline \multirow[t]{12}{*}{1.5 .5} & Nuisance (pollution, noise, etc) & 2.5 . & Ecological sustainability & & \\
\hline & & 2.5.1. & Building materials & & \\
\hline & & 2.5 .2 & Energy consumption & & \\
\hline & & 2.5.3. & $\begin{array}{l}\text { Generating energy from } \\
\text { renewable sources }\end{array}$ & & \\
\hline & & 2.5 .4 & $\begin{array}{l}\text { Greenhouse gas emissions due } \\
\text { to energy consumption }\end{array}$ & & \\
\hline & & 2.5 .5 & Consumption of water & & \\
\hline & & 2.5 .6 & $\begin{array}{l}\text { Generation of waste and } \\
\text { methods of disposal }\end{array}$ & & \\
\hline & & 2.5.7. & Emissions & & \\
\hline & & 2.6. & $\begin{array}{l}\text { Profitability of the } \\
\text { building concept }\end{array}$ & & \\
\hline & & 2.6 .1 & Effectiveness of space & & \\
\hline & & 2.6 .2 & Operational costs & & \\
\hline & & 2.6 .3 & Government charges & & \\
\hline
\end{tabular}

Source: Study based on: Lützkendorf Lorenz (2012), Lorenz (2006); Annual benchmarking report 2012. ISA Research report: benchmarking 2012.

Environmental sustainability was distinguished as one of the sub-criteria of the "real estate" class. The proposed indicators which rating assessment is to be based on acknowledge operating standard parameters in terms of the consumption of utilities, i.e. energy consumption, generation of renewable energy, greenhouse gas emissions, water consumption, waste generation and methods of disposal. It should be noted here that the relevance of the proposed indicators depends largely on the availability of data that can be used to create a benchmark. Rating serves the purpose of the quality assessment of property against the background of the market, hence it is important to refer an index value obtained for a specific property to average market values for the selected parameter.

\section{Market and property rating - recommended scope of the assessment of property with investment potential}

In the evaluation of property development characteristics (investment potential), it is reasonable to use the tools for property assessment which have been implemented by TEGoVA since 2004. They enable the implementation of a standardized and objective analysis that indicates the risks and opportunities of real estate development (EVS 2012). The advantage of the tool is market standard 
assessment (property quality assessment) considering the current and also future-oriented market conditions. The quality features of real estate are assessed in a medium-term perspective, which justifies the applicability of the strategic decision-making method. It is emphasized that the procedure is "future-oriented" (EVS 2012). Rating property with investment potential should therefore include a formal evaluation of its quality, location, market and finances in order to recommend the best possible use.

Scope of assessment of investment property

Table 3

\begin{tabular}{|c|c|c|}
\hline No. & Assessment & Scope of assessment of property with investment potential \\
\hline 1 & Formal & $\begin{array}{l}\text { Integrated assessment of property with regard to public registers and external } \\
\text { databases }\end{array}$ \\
\hline 2 & Property & $\begin{array}{l}\text { Assessment of the quality of property with regard to environmental } \\
\text { sustainability in comparison with the standard market of competitive and } \\
\text { comparable real estate }\end{array}$ \\
\hline 3 & Location & $\begin{array}{l}\text { Assessment of location (economic conditions) compared with the market } \\
\text { standard of competitive and comparable property }\end{array}$ \\
\hline 4 & Market & $\begin{array}{l}\text { Assessment of property market value compared with changes in markets and } \\
\text { economy which determine changes in the mid-term prospect }\end{array}$ \\
\hline 5 & Finances & Rating of cash flow stability for current and planned usage \\
\hline 6 & Recommendations & $\begin{array}{l}\text { Strategic assessment of property in relation to the optimal method of use in the } \\
\text { context of change potential }\end{array}$ \\
\hline
\end{tabular}

Source: Own study.

Rating leads to the collection of key data from various internal and external sources. It comprises the results of market analyses, environmental analyses, valuations and other information needed for the synthetic assessment of property, comparison with other properties (in the process of benchmarking), and ranking in terms of the order of investment projects to be implemented. Analyses of the largest possible scope ought to be applied in relation to strategic development and speculation property.

According to the authors, it is necessary to adopt an objective approach, but only with respect to market characteristics identified on the basis of investor preferences, the measure of which will be the diversification of prices and rents, and the extent of risk. The proposed use of average parameters (KPIs-Key Performance Indicators or KCIs-Key Control Indicators) for the "scaling of the market" is primarily aimed at standardizing the evaluation by considering typical parameters and indicating their average (or best) market level. For this purpose, the results of independent assessment or benchmarks (market rates) are used, the latter serving as a point of reference in analyses.

The information obtained on investment property in the so-called benchmarking process is used for its economic evaluation in comparison to facilities determining a market standard for a given property type, and applies to technical, operational, economic, and financial characteristics. This requires the use of parameters characterizing both the economic and financial situation of individual facilities, as well as average market indicators. Average market indicators are used in analyses, including comparative ones, in assessing (HENZEL, ŚMIETANA, MASZCZYK 2014):

- the investment attractiveness of individual facilities compared to property that defines market standards for its particular type,

- the attractiveness of property compared to other investment instruments.

For a part of rating parameters associated with property assessment (for characteristics such as: property, location, flow quality), the "scaling" concerning the determination of the weights of market characteristics will take into account principles analogous to those used in the estimation of market value. 
Benchmarking should allow a correct diagnosis of property, which constitutes the basis for making the right decisions about the future in order to improve the long-term viability of investments and stabilize cash flows. Information collected systematically in this process will allow for a proactive approach to the management of real estate as an investment. Companies have various possibilities of setting benchmarks. A benchmark can be (ŚMIETANA, RAMIAN 2014):

- developed by the company itself,

- acquired on the market as a result of data sharing within organizations and professional associations, purchased on the market in the form of reports and reference standards.

Key Performance Indicators relating to real estate operating standards are made available by organizations acting on behalf of providers of Facility Management services, i.e. the IFMA ${ }^{4}$ (International Facility Management Association), and ISA $^{5}$ (International Sustainability Alliance). The sources of information about the parameters of the property market standard for relevant local or regional markets are its participants, investors, and service entities.

\section{Conclusion}

Real estate, as an active investment that requires management, is subject to multi-faceted analyses, the results of which will enable an assessment of their characteristics and development opportunities (investment potential). Rating tools which have been proposed and implemented by TEGoVA since 2004 in the area of property valuation may be used as a standardized and objective analysis that indicates the risks and opportunities of real estate development. The authors have indicated the scope of assessment for property with investment potential comprising formal evaluation, the quality of property, its location, market, and finances for the purposes of recommending the best possible use. Standard assessment criteria of property were determined, as were the parameters - indicators of investment property evaluation which take into account the environmental sustainability of buildings and planned investments. Recommended types of economic analyses were proposed for the distinguished types of investment property, including a broadly understood property audit (due diligence analysis) for rental investment properties, and an analysis of the optimal use of property with a potential for an increase in value. What is suggested as the next stage of the study is the application of rating procedures as a useful tool for providing a more objective and standardized assessment of the investment risk. Rating can therefore be considered as an important element of the decision-making process in relation to investment property.

\section{References}

Annual benchmarking report 2012. ISA Research report: benchmarking 2012. ISA - the International Sustainability Alliance, www.theisa.org.

BACZEWSKI J., HANDS K., LATHEM CH. R., 2003, Real Estate Investment Styles, NCREIF.

BElniaK S., GŁusZAK M., ZiĘBA M., 2013, Budownictwo ekologiczne. Aspekty ekonomiczne. (Green Building. Economic Aspects) Wydawnictwo Naukowe PWN, p. 72.

DZIAWGO D., 2010, Credit rating na międzynarodowym rynku finansowym(Credit Rating in the International Financial Market), PWE, p. 93.

European Property and Market Rating: A Valuer's Guide, TEGoVA October 2003, p. 4-6.

EUROPEJSKIE STANDARDY WYCENY 2012 (EUROPEAN VALUATION STANDARDS 2012), Polska Federacja Stowarzyszeń Rzeczoznawców Majątkowych, Warszawa 2013, pp. 72, 100, 175, 178-179, 211-212.

HENZEL H., ŚMIETANA K., MASZCZYK A., 2014, Rynek nieruchomości jako rynek inwestycyjny - parametry oceny, tendencje zmian w latach 2007-2011 (Property Market as an Investment Market - Assessment Parameters andTrends in 2007-2011), Red. nauk. K. Marcinek. Zeszyty Naukowe "Studia Ekonomiczne", Wydawnictwo Uniwersytetu Ekonomicznego w Katowicach (po recenzji w druku).

KOWALCZYK L., 2006, Praktyczne i teoretyczne aspekty badania wiarygodności firmy (Practical and Theoretical Aspects of Company Credibility), DIFIN, p. 40.

KUCHARSKA-STASIAK E., 2006, Nieruchomość w gospodarce rynkowej (Property in Market Economy), Wydawnictwo Naukowe PWN, pp. 210, 253-264.

\footnotetext{
4 Www.ifma.org.

${ }^{5}$ www.theisa.org.
} 
KUCHARSKA-STASIAK E., 2012, In search of the highest and best use of real estate, Topical Issues in the Valuation and Application of Market Value, Scientific Monograph, Volume 17, Number 1, Polish Real Estate Scientific Society, pp. 21-33.

KONOWALCZUK J., RAMIAN T., 2012, The market value of operational corporate real estate, Topical Issues in the Valuation and Application of Market Value, Scientific Monograph, Volume 17, Number 1, Polish Real Estate Scientific Society, pp. 55-75.

LorEnZ D.P., 2006, The Application of Sustainable Development Principles to the Theory and Practice of Property Valuation, Universität Karlsruhe, School of Economics, Karlsruhe 2006, pp. 210-211.

LÜTZKENDORF T., LORENZ D., 2012, Integrating Sustainability Issues into Property Risk Assessment - An Approach to Communicate the Benefits of Sustainable Buildings, Universität Karlsruhe, School of Economics, Karlsruhe, pp. 10-11.

LÜTZKENDORF T., LORENZ D., 2007, Integrating sustainability into property risk assessments for market transformation, Building Research \& Information, Volume 35, Issue 6, pp. 644-661.

LÜTZKENDORF T., LORENZ D., 2005, Sustainable property investment: valuing sustainable buildings through property performance assessment, Building Research \& Information, Volume 33, Issue 3, pp. 212-234.

MARCINEK K., 2012, Społecznie odpowiedzialne inwestowanie na rynku nieruchomości(Socially Responsible Investing in the Property Market), Inwestycje i nieruchomości. Wybrane zagadnienia (Investment and Real Estate. Selected Issues), Zeszyt Naukowy „Studia Ekonomiczne” nr 104, Wydawnictwo Uniwersytetu Ekonomicznego w Katowicach, pp. 163-185.

NALEPKA A., 2006, Zarządzanie nieruchomościami. Wybrane zagadnienia (Property Management. Selected Issues.), Wydawnictwo Akademii Ekonomicznej w Krakowie.

RENIGIER-BIŁOZOR M, WIŚNIEWSKI R., 2012, Rating rynków nieruchomości - analiza teoretyczna (Rating in Property Markets - Theoretical Analysis), Journal of the Polish Real Estate Scientific Society, Vol. 20 (2), p. 68.

ŚMIETANA K, RAMIAN T., 2014, Analiza ekonomiczna nieruchomosci inwestycyjnych (Economic Analysis of Investment Property), Wydawnictwo Uniwersytetu Ekonomicznego w Katowicach (po recenzji, w druku).

ŚMIETANA K., 2013, Diversification principles of real estate portfolio, Real Estate Management and Valuation, vol. 22, no. 1, pp. 53-59.

STACHURA E., 2007, Marketing na rynku nieruchomości (Marketing in Property Market), Polskie Wydawnictwo Ekonomiczne, Warszawa, pp. 49-50.

WóJCICKA A., 2010, Szacowanie prawdopodobieństwa niewyptacalności firmy na podstawie wybranych metod oceny ryzyka kredytowego (Estimating the Probability of Insolvency of a Company on the Basis of Selected Methods for the Assessment of Credit Risk). Uniwersytet Ekonomiczny w Poznaniu, rozprawa doktorska, p. 59.

Zarzadzanie nieruchomościami komercyjnymi (Commercial Property Management), 2006, Red. nauk. I. Foryś, Poltext, Warszawa, p. 37. 